\title{
Induction of increased thermotolerance in Saccharomyces cerevisiae may be triggered by a mechanism involving intracellular $\mathrm{pH}$
}

\author{
P. J. COOTE, ${ }^{*}$ M. B. Cole and M. V. Jones \\ Unilever Research, Colworth Laboratory, Sharnbrook, Bedford MK44 ILQ, UK
}

(Received 21 January 1991; revised 7 March 1991; accepted 25 March 1991)

\begin{abstract}
Incubation of Saccharomyces cerevisiae at sub-lethal temperatures results in an increase in thermotolerance. This process is dependent not only on the sub-lethal temperature but also on the duration of sub-lethal heating. This indicates that the mechanism inducing thermotolerance is a time/temperature dose response. Other factors that induce thermotolerance include exposure to ethanol, sorbic acid and low external $\mathrm{pH}$ values. These factors induce thermotolerance after incubation in the presence of protein synthesis inhibitors, and they are all known to affect the intracellular $\mathrm{pH}\left(\mathrm{pH}_{\mathrm{i}}\right)$. The acquisition of increased thermotolerance is minimal with sub-lethal heating under neutral external $\mathrm{pH}$ conditions. However, when the external $\mathrm{pH}$ is reduced to $4 \cdot 0$ the level of induced thermotolerance increases to a maximum value. Using a specific ATPase inhibitor, diethylstilboestrol (DES), ATPase activity was shown to be essential for the cell to survive heat stress. In addition, measurement of acid efflux, or ATPase activity, revealed that proton pumping from the cell increased by approximately $50 \%$ at sublethal temperatures that induce thermotolerance. This work has clearly implicated $\mathrm{pH}_{\mathrm{i}}$ perturbation as the triggering mechanism conferring thermotolerance on $S$. cerevisiae.
\end{abstract}

\section{Introduction}

Mild heat stress, usually above the normal temperature range for growth, has been shown to increase the thermotolerance of a wide range of micro-organisms when subjected to a subsequent heat challenge (McAlister \& Finkelstein, 1980; Plesofsky-Vig \& Brambl, 1985; Mackey \& Derrick, 1986). This stress response, more commonly known as the heat-shock response, may have implications for microbiological safety during food processing, particularly because the phenomenon is ubiquitous and almost certainly occurs in both foodspoilage and pathogenic organisms (Mackey \& Derrick, 1987; Yamamori \& Yura, 1982; Lindquist, 1986; Farber \& Brown, 1990). In addition to the acquisition of thermotolerance, the stress response has been largely characterized by the expression and synthesis of a unique set of proteins: the heat-shock proteins (HSPs). However, the precise role of these proteins in the acquisition of thermotolerance is still unclear. Some have been implicated in cellular recovery following heat stress (Lindquist \& Craig, 1988) and others appear to be directly involved in the thermotolerance mechanism

Abbreviations: DES, diethylstilboestrol; HSP, heat-shock protein; MEB, malt extract broth; $\mathrm{pH}_{i}$, intracellular $\mathrm{pH}$.
(Borkovich et al., 1989; Finley et al., 1987). Perhaps the most convincing evidence for a specific protein involvement in thermotolerance comes from the HSP104 gene mutants in yeast (Sanchez \& Lindquist, 1990). In cells with this deletion, full expression of thermotolerance is prevented but substantial protection is observed for the first $5 \mathrm{~min}$ of heat stress. Other evidence suggests that the synthesis of new proteins is not required for the acquisition of thermotolerance (Petko \& Lindquist, 1986; Finkelstein \& Strausberg, 1983; Hall, 1983; Watson et al., 1984; Barnes et al., 1990). These contradictions may be resolved if both protein-synthesisdependent and independent mechanisms are involved in thermotolerance.

In addition to sub-lethal heating, many other stress factors are known to induce thermotolerance and the synthesis of HSPs for example, ethanol (Plesset et al., 1982), metal ions (Levinson et al., 1980), cellular trauma (White \& Currie, 1982) and respiratory chain uncouplers (Ashburner \& Bonner, 1979). Many of these factors are also known to cause perturbations in the intracellular $\mathrm{pH}$ $\left(\mathrm{pH}_{\mathrm{i}}\right)$ of the cell (Weitzel et al., 1987; Eraso \& Gancedo, 1987; Leao \& van Uden, 1984). Changes in $\mathrm{pH}_{\mathrm{i}}$ may regulate important cellular functions (Busa \& Nuccitelli, 1984). For example, $\mathrm{pH}_{\mathrm{i}}$ is critical to the activity of many enzymes with specific $\mathrm{pH}$ optima, including the mem- 
brane ATPase (Willsky, 1979) which is responsible for maintaining intracellular pH homeostasis in Saccharomyces cerevisiae (Serrano, 1980; Goffeau \& Slayman, 1981). Recently therefore, it has been proposed that a decrease in $\mathrm{pH}_{\mathrm{i}}$ correlates with the induction of HSPs (Weitzel et al., 1987). Hence, depression of $\mathrm{pH}_{\mathrm{i}}$ is implicated as a trigger for stress-induced thermotolerance.

In this study, the effects of sub-lethal heat and other stress factors on the ability of $S$. cerevisiae to survive a subsequent 'lethal' temperature have been characterized and the necessity for protein synthesis examined.

\section{Methods}

Organism and growth conditions. Saccharomyces cerevisiae (strain CMC 3236) was grown aerobically to late exponential phase at $25^{\circ} \mathrm{C}$ in malt extract broth (MEB, Oxoid). Viability after various heat treatments was determined by resuscitation for $30 \mathrm{~min}$ followed by serial dilution of suspensions in MEB and plating on plate count agar (Oxoid).

Effect of pre-incubation time and temperature on thermotolerance. A cell suspension was prepared from an exponential culture grown in MEB which had been centrifuged, washed, resuspended in fresh broth at a concentration of approximately $10^{8}$ cells $\mathrm{ml}^{-1}$ and allowed to resuscitate at room temperature for $30 \mathrm{~min}$. Aliquots $(0.5 \mathrm{ml})$ of suspension were heated in a modified thermocouple block calibrator (DB-40L) with a TP-16 time/temperature programmer (Techne) as previously described (Coote et al., 1991) at a range of sub-lethal temperatures between 34 and $45^{\circ} \mathrm{C}$ for periods of $20-60 \mathrm{~min}$. Sublethally heated cells were then immediately exposed to a lethal temperature of $52{ }^{\circ} \mathrm{C}$ for $10 \mathrm{~min}$ in the same apparatus. In control experiments, cells were heated as above at $52^{\circ} \mathrm{C}$ for $10 \mathrm{~min}$ without pre-treatment. After heating, all samples were instantly cooled to $20^{\circ} \mathrm{C}$ and viable counts were determined.

Induction of thermotolerance by exposure to other reagents. Thermotolerance after exposure to ethanol and sorbic acid was determined by resuspending the washed cell suspension $(1 \mathrm{ml})$ in MEB containing either $6 \%(\mathrm{v} / \mathrm{v})$ ethanol or $9 \mathrm{~mm}$-sorbic acid. The $\mathrm{pH}$ of the broth was adjusted to either $\mathbf{6 . 0}$ or $\mathbf{4 . 5}$. Cells were resuspended in each reagent for $1,2,10,20$ or $60 \mathrm{~min}$ before being centrifuged and resuspended in fresh MEB (pH 6.0 or 4.5 ). The samples were then heated using a time/temperature programmer at $52{ }^{\circ} \mathrm{C}$ for $10 \mathrm{~min}$ and cell viability was determined.

Protein synthesis inhibition. Cultures grown in MEB were centrifuged and resuspended in fresh broth with or without cycloheximide $(100 \mu \mathrm{g}$ $\mathrm{ml}^{-1}$, Sigma) and chloramphenicol (4 $\mathrm{mg} \mathrm{ml}^{-1}$, Sigma). Following incubation at $25^{\circ} \mathrm{C}$ with shaking for $30 \mathrm{~min}$, cells were centrifuged and resuspended in the original volume of fresh broth. Samples $(1 \mathrm{ml})$ of each were centrifuged (MSE Microcentaur) at 13000 r.p.m. for $30 \mathrm{~s}$ and subjected to the following pre-treatments prior to a lethal heat stress. Pre-treatment consisted of either resuspension in fresh broth plus sub-lethal heating $\left(40^{\circ} \mathrm{C}, 60 \mathrm{~min}\right)$, or resuspension in fresh broth plus sorbic acid $\left(9 \mathrm{mM}, 20^{\circ} \mathrm{C}, 60 \mathrm{~min}\right)$ or resuspension in fresh broth plus ethanol $\left(6 \%, 20^{\circ} \mathrm{C}, 60 \mathrm{~min}\right)$. All samples were then centrifuged, resuspended in fresh broth and heated at $52{ }^{\circ} \mathrm{C}$ for $10 \mathrm{~min}$ as described above. The control culture was given no pre-treatment prior to heat stress at $52{ }^{\circ} \mathrm{C}$.
Effect of $p H$ on thermotolerance. Separate overnight cultures were centrifuged and resuspended in $90 \mathrm{ml}$ of unbuffered MEB adjusted to $\mathrm{pH} 2 \cdot 0,3 \cdot 0,4 \cdot 0,5 \cdot 0,6 \cdot 0,7 \cdot 0$ or $8 \cdot 0$ with $\mathrm{HCl} / \mathrm{NaOH}$. After incubation at $25^{\circ} \mathrm{C}$ with shaking for $1 \mathrm{~h}$, samples $(1 \mathrm{ml})$ were removed and separately heated in a time/temperature programmer for $25,30,35,40,50$ or $60 \mathrm{~min}$ at $40^{\circ} \mathrm{C}$, then at $52^{\circ} \mathrm{C}$ for $10 \mathrm{~min}$ in the same apparatus. Control cultures at each pH were heated at 40 or $52^{\circ} \mathrm{C}$ only.

Determination of acid efflux rate. Overnight cultures were resuspended in sterile distilled water $\left(1.5\right.$ to $3 \mathrm{mg}$ dry wt ml $\left.\mathrm{m}^{-1}\right)$ and $15 \mathrm{ml}$ samples placed in a magnetically stirred water-jacketed vessel at $25^{\circ} \mathrm{C}$. A Corning ion analyser $255 \mathrm{pH}$ meter connected to a BBC Goerz Metrawatt SE 120 chart recorder (ABB Goerz) was used to monitor the suspension $\mathrm{pH}$, which was adjusted to 4.5 with $\mathrm{HCl}$. The system was calibrated using $50 \mu \mathrm{l}$ aliquots of $\mathrm{HCl}$ and $\mathrm{NaOH}(0.01 \mathrm{M})$. Glucose $(0.1 \%)$ was added to initiate proton pumping. Acid efflux was monitored for $5 \mathrm{~min}$ before the system was recalibrated and adjusted to $\mathrm{pH} 4.5$. The rate of acid efflux was determined as described by Cole $\&$ Keenan (1987) and expressed in molar equivalents of $\mathrm{HCl}$. To measure the rate of acid effux after thermal stress, separate cell suspensions were incubated in a water bath at temperatures between 5 and $49^{\circ} \mathrm{C}$ for $30 \mathrm{~min}$. Prior to acid efflux measurements, the temperatures of stressed samples were allowed to equilibrate to $25^{\circ} \mathrm{C}$ in the water-jacketed vessel.

The acid efflux rate was also determined in the presence of the membrane ATPase inhibitor diethylstilboestrol (DES, Sigma). Immediately after the addition of glucose, DES $\left(2.7 \mathrm{mg} \mathrm{ml}^{-1}\right.$ in methanol) was added at a concentration of $5-100 \mu \mathrm{g} \mathrm{ml}^{-1}$. The thermal inactivation of cells, when heated at $53^{\circ} \mathrm{C}$ following exposure to DES and resuspension in fresh broth, was determined as described above.

\section{Results}

\section{Induction of thermotolerance by exposure to sub-lethal heating}

When $S$. cerevisiae was incubated at a series of sub-lethal temperatures $\left(37,40,43\right.$, and $\left.45^{\circ} \mathrm{C}\right)$ for time periods varying from 0 to $60 \mathrm{~min}$, an increased level of thermotolerance at $52^{\circ} \mathrm{C}$ was observed (Fig. 1). A preincubation over $60 \mathrm{~min}$ at $34^{\circ} \mathrm{C}$ resulted in no significant increase in thermotolerance. However, as the temperature of sub-lethal heating or the holding time at a sublethal temperature increased, there was a comparable increase in the levels of thermotolerance induced. This occurred at all sub-lethal temperatures above $34^{\circ} \mathrm{C}$ with up to $40 \mathrm{~min}$ incubation, but after longer incubation times, thermotolerance started to decline. The maximum thermotolerance occurred after a $40 \mathrm{~min}$ incubation at $45^{\circ} \mathrm{C}$ and represented a 300 -fold increase in survivors compared to a non-sub-lethally heated control.

\section{Induction of thermotolerance by exposure to other reagents}

Prior exposure of S. cerevisiae to ethanol $(6 \%)$ and sorbic acid $(9 \mathrm{mM})$ resulted in the induction of increased thermotolerance of cells held at $52{ }^{\circ} \mathrm{C}$ for $10 \mathrm{~min}$ (Fig. 2). 


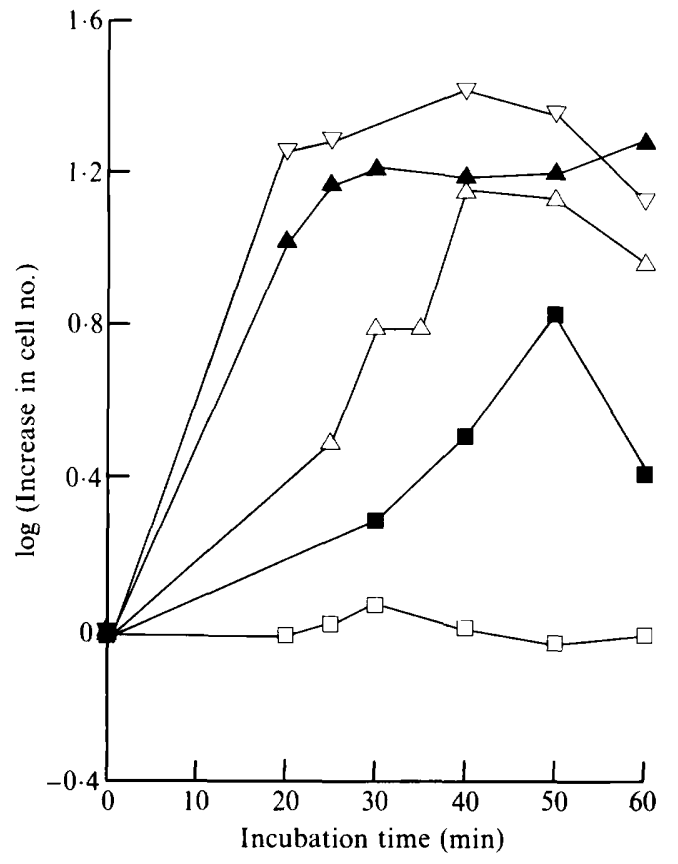

Fig. 1. Effect of incubation time at $34(\square), 37(\square), 40(\triangle), 43(\Delta)$ and $45^{\circ} \mathrm{C}(\nabla)$ on the acquisition of increased thermotolerance in $S$. cerevisiae. Mid-exponential phase cells, grown at $25^{\circ} \mathrm{C}$, were harvested and resuspended in fresh $\mathrm{MEB}$ before incubation at the above temperatures prior to heating at $52{ }^{\circ} \mathrm{C}$ for $10 \mathrm{~min}$. Log (increase in cell no.) represents the increase in cell numbers due to sub-lethal heating when cells are subjected to a lethal temperature, i.e. $\log$ (increase in cell no. $)=\log$ survivors (sublethally heated) $-\log$ survivors $\left(25^{\circ} \mathrm{C}\right)$ after heating at $52{ }^{\circ} \mathrm{C}$ for $10 \mathrm{~min}$. The data are from a representative experiment.

This occurred when the external $\mathrm{pH}$ of the medium was either 6.0 or 4.5 . However, with the exception of sorbic acid, thermotolerance was induced more rapidly and to a higher level at the lower $\mathrm{pH}$ of $4 \cdot 5$. Sorbic acid increased thermotolerance within $10 \mathrm{~min}$ of initial exposure at both pH 6.0 and 4.5 (Fig. $2 a$ and $b$, respectively). The initial rate of induction by sorbic acid at both $\mathrm{pH}$ values was similar. However, the number of survivors after $60 \mathrm{~min}$ was higher at the lower $\mathrm{pH}$ value. In contrast to sorbic acid, the increase in thermotolerance as a result of exposure to ethanol occurred more slowly and was dependent on external pH. At pH 6.0 (Fig. $2 a$ ) thermotolerance was induced within $60 \mathrm{~min}$, and at $\mathrm{pH} 4.5$ (Fig. $2 b$ ) within $20 \mathrm{~min}$. The effect of lowering $\mathrm{pH}$ alone was shown when cells were resuspended in fresh broth in the absence of sorbic acid or ethanol but at the lower $\mathrm{pH}$ of 4.5. Increased thermotolerance was induced within $20 \mathrm{~min}$, but not to the same level as that induced by sorbic acid and ethanol. Clearly, reducing the external $\mathrm{pH}$ value enhances the induction of increased thermotolerance.
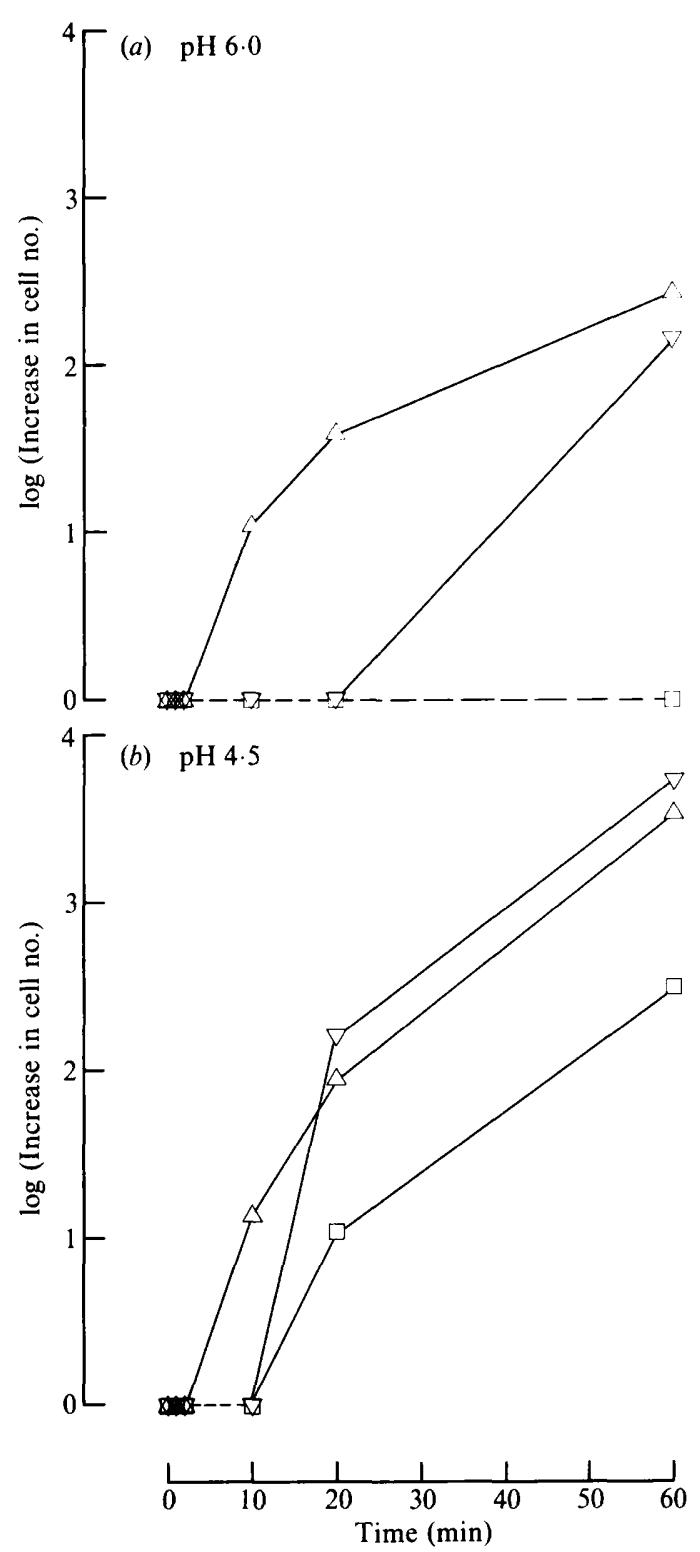

Fig. 2. Effect of incubation time on the acquisition of increased thermotolerance in S. cerevisiae in the presence of fresh MEB ( $\square), 6 \%$ ethanol $(\nabla)$, and $9 \mathrm{~mm}$-sorbic acid $(\triangle)$. Following pre-treatment, cells were resuspended in MEB and heated at $52^{\circ} \mathrm{C}$ for $10 \mathrm{~min}$. $\mathrm{Log}$ (increase in cell no.) indicates the increase in surviving cells following pre-treatment, compared to the untreated control. The data are from a representative experiment. (a) External pH of $6.0 ;(b)$ external $\mathrm{pH}$ of $4 \cdot 5$.

\section{The role of protein synthesis}

Pre-incubation for $30 \mathrm{~min}$ with the protein synthesis inhibitors cycloheximide $\left(100 \mu \mathrm{g} \mathrm{ml}^{-1}\right)$ and chloramphenicol $\left(4 \mathrm{mg} \mathrm{ml}^{-1}\right)$ (Watson et al., 1984) failed to prevent the induction of increased thermotolerance at $52{ }^{\circ} \mathrm{C}$ by sub-lethal heating, ethanol, or sorbic acid (Table 1). 
Table 1. Effect of protein synthesis inhibition on the acquisition of thermotolerance in $S$. cerevisiae

Thermotolerance was measured at $52{ }^{\circ} \mathrm{C}$ for $10 \mathrm{~min}$ in $S$. cerevisiae after treatment with protein synthesis inhibitors, and compared to control cells. Thermotolerance was induced by sub-lethal heat $\left(40{ }^{\circ} \mathrm{C}, 60 \mathrm{~min}\right)$, ethanol $(6 \%, 60 \mathrm{~min})$, and sorbic acid $(9 \mathrm{~mm}$, $60 \mathrm{~min}$ ). Figures in parentheses indicate increase in log numbers due to exposure to sub-lethal heat, ethanol or sorbic acid.

\begin{tabular}{lll}
\hline \hline & \multicolumn{2}{c}{$\log \left(\right.$ Cell no. $\left.\mathrm{ml}^{-1}\right)$} \\
\cline { 2 - 3 } & With inhibitors* & No inhibitors \\
\hline Initial cell number & 8.28 & 8.10 \\
Cell number after lethal heating & $5.77(+0)$ & $5.68(+0)$ \\
$6 \%$ ethanol & $7.44(+1.67)$ & $6.57(+0.89)$ \\
9 mM-sorbic acid & $6.83(+1.06)$ & $6.99(+1.31)$ \\
$40^{\circ} \mathrm{C}$ & $7.57(+1.80)$ & $7.99(+2.31)$ \\
\hline \hline
\end{tabular}

* Cycloheximide $\left(100 \mu \mathrm{g} \mathrm{ml}^{-1}\right)$ and chloramphenicol $\left(4 \mathrm{mg} \mathrm{ml}^{-1}\right)$.

\section{Effect of $\mathrm{pH}$ on thermotolerance}

The effect of incubating $S$. cerevisiae for $1 \mathrm{~h}$ at different $\mathrm{pH}$ values on viability at a lethal temperature $\left(52{ }^{\circ} \mathrm{C}\right)$ was determined both with and without pre-incubation at the sub-lethal temperature of $40^{\circ} \mathrm{C}$ (Fig. 3). In both cases thermotolerance was expressed as the cell number above or below that surviving at $\mathrm{pH} 5 \cdot 0$, the starting $\mathrm{pH}$ of the culture medium (MEB). External pH changes alone had a marked effect on the degree of thermotolerance induced. A mild acidification to $\mathrm{pH} 4.0$ increased the number of survivors approximately 100 -fold. At all other $\mathrm{pH}$ values the number of survivors declined approximately tenfold. The effect of adding a sub-lethal incubation at $40{ }^{\circ} \mathrm{C}$ was to increase thermotolerance at all $\mathrm{pH}$ values. Maximum thermotolerance was again induced at the mild acid $\mathrm{pH}$ values of 4.0 and $5 \cdot 0$ (at least a 1000 -fold increase in thermotolerance). Both decreasing the external $\mathrm{pH}$ to 3.0 and 2.0 , and increasing it to 6.0 and 7.0 , reduced the level of thermotolerance compared to the maximum induced at $\mathrm{pH} 4.0$. However, unexpectedly, when the external $\mathrm{pH}$ was increased to 8.0 , thermotolerance increased again. This clear effect of $\mathrm{pH}$ on the degree of thermotolerance induced prompted an examination of $\mathrm{pH}_{\mathrm{i}}$ and particularly the membrane ATPase which is involved in regulation of $\mathrm{pH}_{\mathrm{i}}$.

\section{Thermotolerance at $52^{\circ} \mathrm{C}$ after pre-incubation with the specific membrane ATPase inhibitor DES}

Control cells exposed to $100 \mu \mathrm{g}$ DES $\mathrm{ml}^{-1}$ at $20^{\circ} \mathrm{C}$ showed little loss in viability over a period of $6 \mathrm{~h}$. Cells heated at $52^{\circ} \mathrm{C}$ with no pre-treatment with DES started to lose viability after $8 \mathrm{~min}$. However, cells pre-incubated

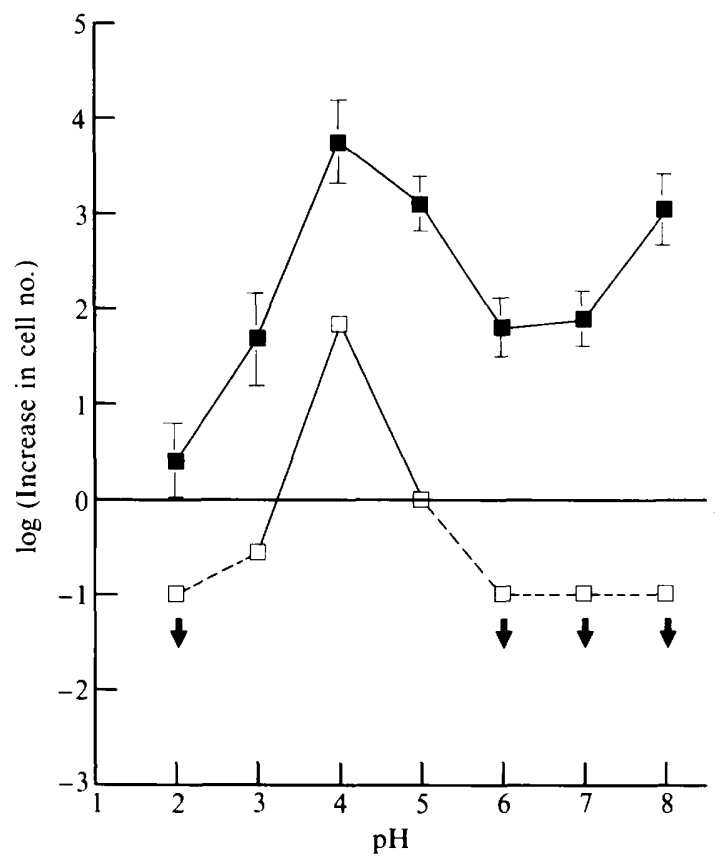

Fig. 3. Effect of $\mathrm{pH}$ and effect of $\mathrm{pH}$ and pre-incubation at $40^{\circ} \mathrm{C}$ on the thermotolerance of $S$. cerevisiae compared to resuspension in fresh $\mathrm{MEB}$ at $\mathrm{pH} 5 \cdot 0$. Thermotolerance was determined after treatment at $52{ }^{\circ} \mathrm{C}$ for $10 \mathrm{~min}$. Log (increase in cell no.) indicates the increase or decrease in cell number due to resuspension in broth at various $\mathrm{pH}$ values $(\square)$, or increase in cell number due to resuspension in broth at various $\mathrm{pH}$ values and incubation at $40^{\circ} \mathrm{C}$ for various times $(\boldsymbol{D})$ (error bars indicate the mean cell numbers of six pre-incubation times at $40^{\circ} \mathrm{C}$ ). Arrows indicate that cell numbers are less than the points indicated on the graph.

in DES and then heated to $52{ }^{\circ} \mathrm{C}$ were dramatically less thermotolerant (Fig. 4). Exposure to $27 \mu \mathrm{g}$ DES ml ${ }^{-1}$ resulted in a sixfold $\log$ reduction in numbers after $4 \mathrm{~min}$ and exposure to $67 \mu \mathrm{g} \mathrm{DES} \mathrm{ml} l^{-1}$ resulted in an eightfold $\log$ reduction within $1 \mathrm{~min}$. These results suggest that the membrane ATPase has a key role in maintaining cell viability during heat stress.

\section{Effect of sub-lethal heating and DES on acid efflux rate}

Inhibition of glucose-stimulated acid efflux in the presence of DES was apparent with the lowest concentration tested $\left(5 \mu \mathrm{g} \mathrm{ml}^{-1}\right)$ and increased to approximately $90 \%$ with the addition of $25 \mu \mathrm{g} \mathrm{DES} \mathrm{ml} \mathrm{g}^{-1}$, and to $100 \%$ with $50 \mu \mathrm{g} \mathrm{DES} \mathrm{ml} \mathrm{m}^{-1}$ and above (Fig. 5). When cells grown at $25^{\circ} \mathrm{C}$ were subjected to a sub-lethal heat stress at 31 or $41{ }^{\circ} \mathrm{C}$, their rate of acid efflux was increased by 40 and $46 \%$, respectively, over the control rate measured at $25^{\circ} \mathrm{C}$ (Fig. 6). However, after sub-lethal heat stress at 45 and $49{ }^{\circ} \mathrm{C}$, acid efflux was reduced by 17 and $48 \%$, respectively. Thermotolerance after the same tempera- 


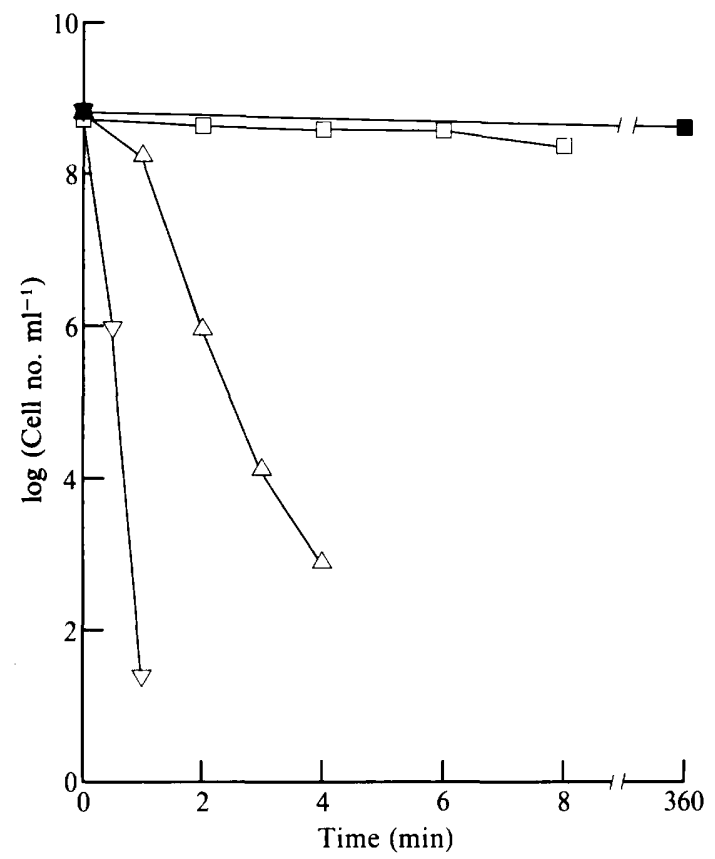

Fig. 4. Effect of a $30 \mathrm{~min}$ pre-incubation with two concentrations of DES on the thermal inactivation of $S$. cerevisiae. Mid-exponentialphase cells were harvested and resuspended in fresh MEB with $27 \mu \mathrm{g}$ $\operatorname{DES~ml} l^{-1}(\triangle), 67 \mu \mathrm{g} \mathrm{DES} \mathrm{ml}^{-1}(\nabla)$ or without DES $(\square)$. After $30 \mathrm{~min}$, cells were resuspended in broth without DES and heated at $52^{\circ} \mathrm{C}$. The effect of incubation in $100 \mu \mathrm{g} \mathrm{ml}^{-1}$ DES only is shown ( $\square$ ).

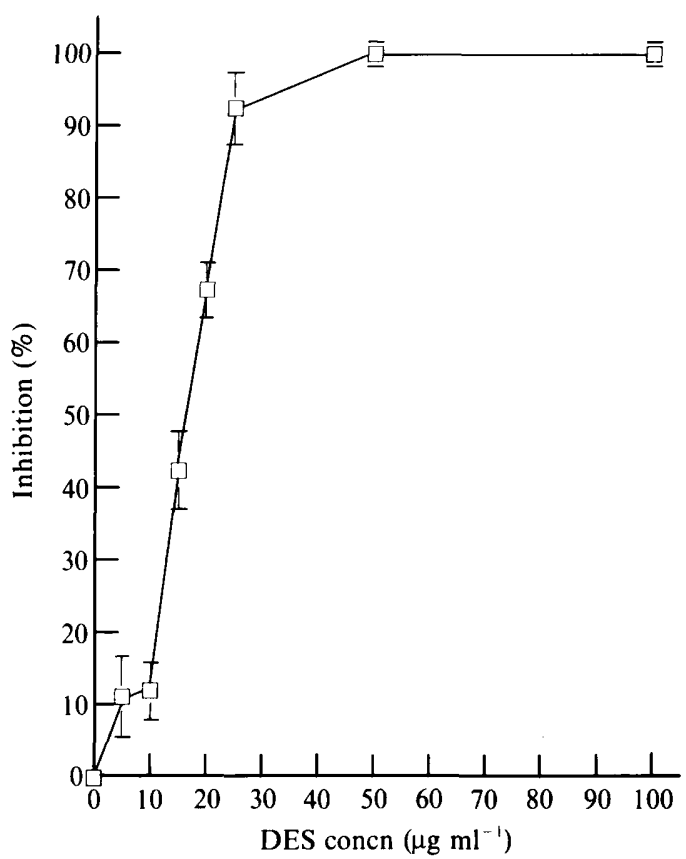

Fig. 5. Effect of the addition of DES on the percentage inhibition of the total acid efflux rate in $S$. cerevisiae following addition of glucose $\left(10 \mathrm{~g} \mathrm{l}^{-1}\right)$ (error bars indicate standard deviation of the mean of three experiments) measured at $25^{\circ} \mathrm{C}$.

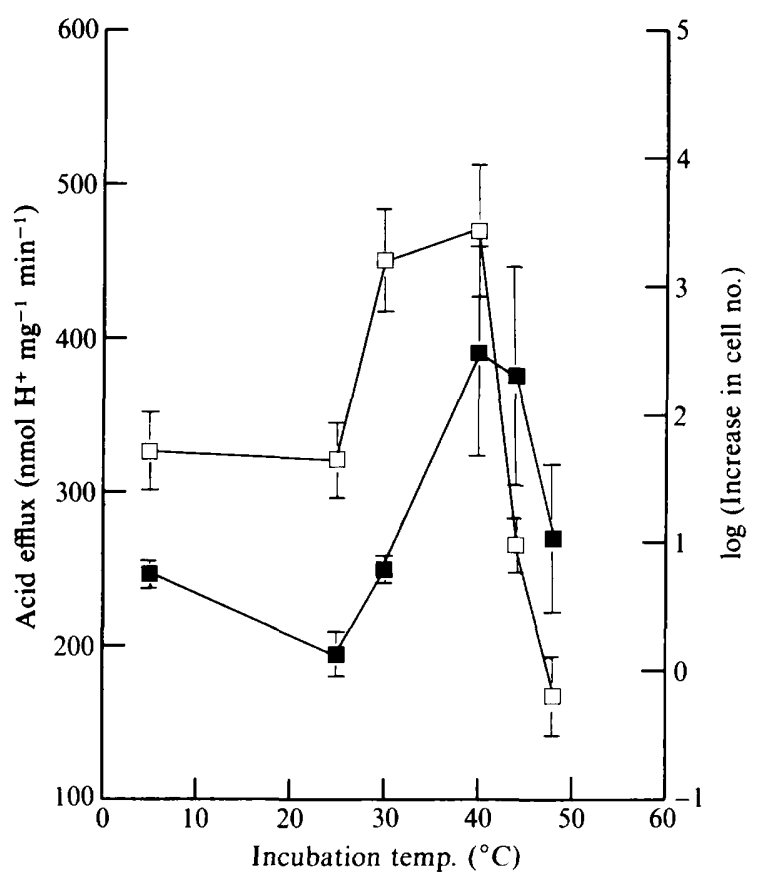

Fig. 6. Effect of incubation temperature $(30 \mathrm{~min}$ in sterile distilled water) on the acid efflux rate following addition of glucose $\left(10 \mathrm{~g} \mathrm{l}^{-1}\right)$ (口) (error bars indicate standard deviation of the mean of 11 experiments), measured at $25^{\circ} \mathrm{C}$; and the acquisition of increased thermotolerance following addition of glucose $\left(10 \mathrm{~g} \mathrm{l}^{-1}\right)(\boldsymbol{D})$ (error bars indicate standard deviation of the mean of three experiments) in $S$. cerevisiae. Log (increase in cell no.) indicates the increase in cell numbers due to sub-lethal heating when cells are subjected to a lethal temperature of $52^{\circ} \mathrm{C}$ for $10 \mathrm{~min}$.

ture treatments revealed a slight increase after preincubation at $31{ }^{\circ} \mathrm{C}$, but a larger increase (by 100 -fold) after pre-incubation at 41 and $45^{\circ} \mathrm{C}$. At $49^{\circ} \mathrm{C}$ thermotolerance is reduced, but it still remains higher than that induced at $31^{\circ} \mathrm{C}$.

\section{Discussion}

A number of studies have examined the range of preincubation temperatures which will afford the microbial cell an increased tolerance to a subsequent lethal temperature. The onset of the response generally occurs at temperatures close to the maximum for growth. The upper temperature inducing an increase in thermotolerance is limited as the incubation temperature approaches values that will have a lethal effect in their own right.

From this work the onset of the acquisition of increased thermotolerance in $S$. cerevisiae appears to be between 34 and $37^{\circ} \mathrm{C}$. At temperatures above $45^{\circ} \mathrm{C}$ preincubation begins to have a lethal effect in its own right (data not shown). The degree of protection afforded to a population of cells is related not only to the sub-lethal 
pre-incubation temperature, but also to its duration. Within the range of temperatures that give an increase in heat resistance, higher temperatures not only produce a greater response, with a greater number of cells surviving lethal temperatures, but also produce a quicker response than at lower pre-incubation temperatures. The fact that there is a kinetic relationship between incubation temperature and the degree of increased thermotolerance clearly indicates that the response to sub-lethal heating is not merely 'switched on' at a certain threshold temperature but that the molecular mechanism is a dose response relating to time as well as temperature of stress.

A number of stress factors have been shown to induce the acquisition of increased thermotolerance. These include those that are well known to induce thermotolerance such as mild heat (McAlister \& Finkelstein, 1980) and ethanol (Plesset et al., 1982), but also sorbic acid and low external $\mathrm{pH}$, which has not been previously reported. Many of these factors, including mild heat, are known to reduce the $\mathrm{pH}_{\mathrm{i}}$ value of yeast (Weitzel et al., 1987; Eraso \& Gancedo, 1987; Cole \& Keenan, 1987; Leao \& van Uden, 1984). It follows therefore that a depression in $\mathrm{pH}_{\mathrm{i}}$ is a strong candidate for the triggering mechanism of this response.

The kinetics with which pre-incubation with mild heat, ethanol, and sorbic acid induced increased thermotolerance in this study supports the notion that $\mathrm{pH}_{\mathrm{i}}$ perturbation may play a key role as the stimulus for this response. Sorbic acid causes a rapid onset of increased thermotolerance and weak acids are also known to result in a rapid depression of $\mathrm{pH}_{\mathrm{i}}$ (Cole \& Keenan, 1987; Suomolainen \& Oura, 1955; Ryan \& Ryan, 1972; Krebs et al., 1983). The undissociated species of weak acids are uncharged and enter the yeast cell extremely rapidly (Macris, 1975). Upon entering the relatively high $\mathrm{pH}_{\mathrm{i}}$ environment of the cell, the molecular species dissociates, releasing protons and hence depressing $\mathrm{pH}_{\mathrm{i}}$. Mild heat causes a less rapid reduction in $\mathrm{pH}_{\mathrm{i}}$ (Weitzel et al., 1987) and we have shown that the acquisition of increased thermotolerance is also slower. Mild heat presumably reduces $\mathrm{pH}_{\mathrm{i}}$ by making membranes 'leaky' and increasing proton permeability. As the external environment is more acidic than inside the cell, increased proton permeability will allow the passive influx of protons which will depress $\mathrm{pH}_{\mathrm{i}}$. Ethanol is thought to have a similar effect on membranes as mild heat, increasing membrane permeability, and thus affecting $\mathrm{pH}_{\mathrm{i}}$ (Li et al., 1980; Leao \& van Uden, 1984). The onset of increased thermotolerance with ethanol is slower than sorbic-acid-induced resistance but is more rapid when the external $\mathrm{pH}$ value is lower.

If the onset and magnitude of acquired thermotolerance is dependent upon a depression of $\mathrm{pH}_{\mathrm{i}}$ then we would expect to find the response to be minimal with mild heat under conditions where the net movement of protons into the cell will be least. The minimal effect of sub-lethal heating at a neutral external $\mathrm{pH}$ supports this. $\mathrm{The}_{\mathrm{pH}}$ value of $S$. cerevisiae, determined either by the dual radio-labelled isotope method (Conway \& Downey, $1950)$ or by ${ }^{31} \mathrm{P}$-nuclear magnetic resonance (NMR) spectroscopy (Gillies et al., 1981), in MEB (pH 5.0) is between 6.5 and 7.0 (data not shown). When cells are sub-lethally heated at external $\mathrm{pH}$ values close to intracellular values (and hence where the net movement of protons across the membrane will be least) the acquisition of increased thermotolerance is low. As the external $\mathrm{pH}$ value is decreased, and the proton gradient increased, then thermotolerance is enhanced down to a $\mathrm{pH}$ of 4.0. At external $\mathrm{pH}$ values below 4.0 thermotolerance declines, presumably as low $\mathrm{pH}$ values begin to exert a lethal effect in their own right. Unexpectedly, the acquisition of thermotolerance at an external $\mathrm{pH}$ value of 8.0 was greater than that at $\mathrm{pH} 6.0-7 \cdot 0$, perhaps indicating that perturbation of $\mathrm{pH}_{\mathrm{i}}$ in any direction may trigger the response.

The intracellular $\mathrm{pH}$ of $S$. cerevisiae is largely maintained by a membrane bound ATPase (Malpartida \& Serrano, 1981; Serrano, 1980) and to a lesser extent by the secretion of organic acids which have been shown not to rapidly re-enter cells (Sigler et al., 1981). Yeast plasma membrane ATPase is regulated by a variety of factors including $\mathrm{pH}_{\mathrm{i}}$ (Riemersma \& Alsbach, 1974), extracellular $\mathrm{pH}$, glucose, and ATP content of the cells (Serrano, 1980). Although the precise mechanism of acid-mediated activation is not known, synthesis of proteins can be excluded as cycloheximide did not prevent activation by acid pH (Eraso \& Gancedo, 1987). It follows therefore that as intracellular acidification may be the trigger for an increase in thermotolerance, then the activity of this essential enzyme may be important in the response.

Using the specific ATPase inhibitor DES, (Eilam et al., 1984) ATPase activity has been demonstrated to be essential for the cell to survive heat stress. Perhaps more significantly, total acid efflux, a good measure of ATPase activity in yeast, increases when cells are incubated at some temperatures that confer thermotolerance upon the cell. A role of ATPase in the acquisition of thermotolerance is also supported by the recent work of Panaretou \& Piper (1990). pmal.1 mutants of $S$. cerevisiae and Schizosaccharomyces pombe, which show a decreased ATPase activity, also demonstrated a lower tolerance to heat following pre-incubation between 25 and $38^{\circ} \mathrm{C}$ compared to the wild-type. It was suggested by these authors that the ATPase exerts an influence on the extent and duration of HSP synthesis following induction of the heat-shock response.

Whilst the precise mechanism of increased thermotolerance following exposure to sub-lethal heat, weak 
acid and ethanol is not known, the necessity for the synthesis of the majority of HSPs must now be questioned. The present study, and previously reported work (Hall, 1983), has demonstrated that the increase in thermotolerance afforded by such stresses is unaffected by protein synthesis inhibitors. Two other pieces of information suggest that HSP synthesis is not required for increased thermotolerance. First, the rapidity of the response following exposure to sorbic acid is such that it is unlikely, in our belief, that sufficient protein synthesis could take place within this period to confer heat resistance. Second, pulse-labelling experiments (Piper et al., 1986) have shown that yeast cannot synthesize HSPs above $42-43{ }^{\circ} \mathrm{C}$ but our work has demonstrated an increase in thermotolerance at temperatures as high as $45^{\circ} \mathrm{C}$.

To conclude, the present work has clearly implicated $\mathrm{pH}_{\mathrm{i}}$ as the trigger for the acquisition of thermotolerance in $S$. cerevisiae. Furthermore, we postulate that one possible mechanism of increased thermotolerance may simply be due to an increased ability to maintain normal $\mathrm{pH}_{\mathrm{i}}$ values. Recent measurements in our laboratory of $\mathrm{pH}_{\mathrm{i}}$, using ${ }^{31} \mathrm{P}-\mathrm{NMR}$, indeed indicate that pre-incubation at sub-lethal temperatures allows the cell to maintain a higher $\mathrm{pH}_{\mathrm{i}}$ value at a lethal temperature than unstressed cells. Increased thermotolerance following exposure to stress may not be directly related to the synthesis of HSPs, but also to the ability of the cell to maintain a reasonable $\mathrm{pH}_{\mathrm{i}}$ value through the stimulation of the ATPase. Mild perturbation of $\mathrm{pH}_{\mathrm{i}}$ may affect other metabolic functions such as cyclic AMP metabolism (Piper, 1990; Iida, 1988) which have been implicated in the heat-shock response. A unifying explanation of the mechanism of induced thermotolerance will therefore require an understanding of how these diverse metabolic factors interact.

\section{References}

ASHBURNER, M. \& BONNER, J. J. (1979). The induction of gene activity in Drosophila by heat shock. Cell 17, 241-254.

Barnes, C. A., Johnston, G. C. \& Singer, R. A. (1990). Thermotolerance is independent of induction of the full spectrum of heat shock proteins and of cell cycle blockage in the yeast Saccharomyces cerevisiae. Journal of Bacteriology 172, 4352-4358.

Borkovich, K. A., Farrelly, F. W., Finkelstein, D. B., Tanlien, J. \& LINDQUIST, S. (1989). Hsp 82 is an essential protein that is required in higher concentrations for growth of cells at higher temperatures. Molecular and Cellular Biology 9, 3919-3930.

BUSA, W. B. \& NUCCITELlI, R. (1984). Metabolic regulation via intracellular pH. American Journal of Physiology 246, 409-438.

Cole, M. B. \& KeEnan, M. H. J. (1987). Effects of weak acids and external $\mathrm{pH}$ on the intracellular $\mathrm{pH}$ of Zygosaccharomyces bailii, and its implications in weak-acid resistance. Yeast 3, 23-32.

Conway, E. J. \& Downey, M. (1950). pH values of the yeast cell. Biochemical Journal 47, 355-360.
CoOte, P. J., Cole, M. B. \& Holyoak, C. (1991). Thermal inactivation of Listeria monocytogenes during a process simulating temperatures achieved during microwave heating. Journal of Applied Bacteriology 70, (in the Press).

EILAM, Y., LAVI, H. \& GRossowICZ, N. (1984). Effects of inhibitors of plasma membrane ATPase on potassium and calcium fluxes, membrane potential and protonmotive force in the yeast Saccharomyces cerevisiae. Microbios 41, 177-189.

Eraso, P. \& Gancedo, C. (1987). Activation of yeast plasma membrane ATPase by acid $\mathrm{pH}$ during growth. FEBS Letters 224, 187-192.

FARBER, J. M. \& BRown, B. E. (1990). Effect of prior heat shock on heat resistance of Listeria monocytogenes in meat. Applied and Environmental Microbiology 56, 1584-1587.

Finkelstein, D. B. \& Strausberg, S. (1983). Identification and expression of a cloned yeast heat shock gene. Journal of Biological Chemistry 258, 1908-1913.

Finley, D., OzKaynak, E. \& Vashavsky, A. (1987). The yeast polyubiquitin gene is essential for resistance to high temperatures, starvation and other stresses. Cell 48, 1035-1046.

Gillies, R. J., Ugurbil, K., Den Hollander, J. A. \& Shulman, R. G. (1981). ${ }^{31} \mathrm{P}$ NMR studies of intracellular $\mathrm{pH}$ and phosphate metabolism during the cell division cycle of Saccharomyces cerevisiae. Proceedings of the National Academy of Sciences of the United States of America 78, 2125-2129.

Goffeau, A. \& Slayman, C. W. (1981). The proton-translocating ATPase of the fungal plasma membrane. Biochimica et Biophysica Acta 639, 197-223.

HALL, B. G. (1983). Yeast thermotolerance does not require protein synthesis. Journal of Bacteriology 156, 1363-1365.

Krebs, H. A., Wiggins, D., StubBs, M., Sols, A. \& Bedoya, F. (1983). Studies on the mechanism of the antifungal action of benzoate. Biochemical Journal 214, 657-663.

IIDA, H. (1988). Multistress resistance of Saccharomyces cerevisiae is generated by insertion of retrotransposon Ty into the $5^{\prime}$ coding region of the adenylate cyclase gene. Molecular and Cellular Biology 8, 55555560.

LEAO, C. \& VAN UDEN, N. (1984). Effects of ethanol and other alkanols on passive proton influx in the yeast Saccharomyces cerevisiae. Biochimica et Biophysica Acta 774, 43-48.

LeVInSON, W., OPPERMAN, H. \& JACKSON, J. (1980). Transition series metals and sulfhydryl reagents induce the synthesis of four proteins in eukaryotic cells. Biochimica et Biophysica Acta 606, 170-180.

LI, G. C., SHIU, E. C. \& HAHN, G. M. (1980). Similarities in cellular inactivation by hyperthermia or by ethanol. Radiation Research $\mathbf{8 2}$, 257-268.

LINDQUIST, S. (1986). The heat shock response. Annual Review of Biochemistry 55, 1151-1191.

Lindouist, S. \& Craig, E. A. (1988). The heat shock proteins. Annual Review of Genetics 22, 631-677.

MACKEY, B. M. \& DERRICK, C. M. (1986). Elevation of the heat resistance of Salmonella typhimurium by sublethal heat shock. Journal of Applied Bacteriology 61, 389-393.

MaCKey, B. M. \& Derrick, C. M. (1987). The effect of prior heat shock on the thermoresistance of Salmonella thompson in foods. Letters in Applied Microbiology 5, 115-118.

MACRIS, B. J. (1975). Mechanism of benzoic acid uptake by Saccharomyces cerevisiae. Applied Microbiology 30, 503-506.

Malpartida, F. \& Serrano, R. (1981). Proton translocation catalysed by the purified yeast plasma membrane ATPase reconstituted in liposomes. FEBS Letters 131, 351-354.

MCALISTER, L. \& FinKelstein, D. B. (1980). Heat shock proteins and thermal resistance in yeast. Biochemical and Biophysical Research Communications 93, 819-824.

Panaretou, B. \& Piper, P. W. (1990). Plasma-membrane ATPase action affects several stress tolerances of Saccharomyces cerevisiae and Schizosaccharomyces pombe as well as the extent and duration of the heat shock response. Journal of General Microbiology 136, 17631770.

PetKo, L. \& Lindquist, S. (1986). Hsp 26 is not required for growth at high temperatures; nor for thermotolerance, spore development, or germination. Cell 45, 885-894. 
PiPer, P. W. (1990) Interdependance of several heat shock gene activations, cyclic AMP decline and changes at the plasma membrane of Saccharomyces cerevisiae. Antonie van Leeuwenhoek 58, 195-201.

Piper, P. W., Curran, B., Davies, M. W., Lockheart, A. \& Reid, G. (1986). Transcription of the phosphoglycerate kinase gene of Saccharomyces cerevisiae increases when fermentative cultures are stressed by heat shock. European Journal of Biochemistry 161, 525531.

Plesofsky-Vig, N. \& Brambl, R. (1985). Heat shock response of Neurospora crassa: protein synthesis and induced thermotolerance. Journal of Bacteriology 162, 1083-1091.

Plesset, J., Palm, C. \& MCLaughlin, C. S. (1982). Induction of heat shock proteins and thermotolerance by ethanol in Saccharomyces cerevisiae. Biochemical and Biophysical Research Communications 108, 1340-1345.

Riemersma, J. C. \& Alsbach, E. J. J. (1974). Proton translocation during anaerobic energy production in Saccharomyces cerevisiae. Biochimica et Biophysica Acta 339, 274-284.

RYAN, J. P. \& RYAN, H. (1972). The role of intracellular pH in the regulation of cation exchange in yeast. Biochemical Journal 128, 139146.

SANCHEZ, Y. \& LINDQUiST, S. L. (1990). HSP104 required for induced thermotolerance. Science 248, 1112-1115.

SERRANO, R. (1980). Effect of ATPase inhibitors on the proton pump of respiratory deficient yeast. European Journal of Biochemistry 105, 419-424.
Sigler, K., Kotyk, A., Knotkova, A. \& Opekarova, M. (1981). Processes involved in the creation of buffering capacity and in substrate-induced proton extrusion in the yeast Saccharomyces cerevisiae. Biochimica et Biophysica Acta 643, 583-592.

Suomalainen, H. \& OURA, E. (1955). Buffer effect in fermentation solutions. Experimental Cell Research 9, 355-359.

Watson, K., Dunlop, G. \& Cavicchioli, R. (1984). Mitochondrial and cytoplasmic protein synthesis are not required for heat shock acquisition of ethanol and thermotolerance in yeast. FEBS Letters 172, 299-302.

Weitzel, G., Pilatus, U. \& Rensing, L. (1987). The cytoplasmic pH, ATP content and total protein synthesis rate during heat-shock protein inducing treatments in yeast. Experimental Cell Research 170, 64-79.

White, F. P. \& CurRIE, R. W. (1982). A mammalian response to trauma: the synthesis of a $71-\mathrm{kD}$ protein. In Heat Shock: From Bacteria to Man, pp. 379-386. Edited by M. J. Schlesinger, A. Ashburner \& A. Tissieres. Cold Spring Harbor, NY: Cold Spring Harbor Laboratory.

WILLSKY, G. R. (1979). Characterisation of the plasma membrane $\mathrm{Mg}^{2+}$-ATPase from the yeast Saccharomyces cerevisiae. Journal of Biological Chemistry 254, 3326-3332.

YAMAMORI, T. \& YURA, T. (1982). Genetic control of heat-shock protein synthesis and its bearing on growth and thermal resistance in Escherichia coli K12. Proceedings of the National Academy of Sciences of the United States of America 79, 860-864. 